\title{
Evaluation of Yield and Competition Indices for Intercropped Eight Maize Varieties, Soybean and Cowpea in the Zone of Savanna of South-West RD Congo
}

\author{
Pongi Khonde ${ }^{1 *}$, Kabongo Tshiabukole ${ }^{1}$, Mbuya Kankolongo ${ }^{1}$, Stefan Hauser ${ }^{2}$, Mumba Djamba ${ }^{3}$, \\ Kizungu Vumilia ${ }^{4}$, Kabwe Nkongolo 5
}

${ }^{1}$ Programme National Maïs, INERA, Kinshasa, RD Congo

${ }^{2}$ The International Institute of Tropical Agriculture (IITA), Ibadan, Nigeria

${ }^{3}$ Université Pédagogique Nationale, Kinshasa, RD Congo

${ }^{4}$ Direction Scientifique, Biométrie et Expérimentation, Université de Kinshasa, Kinshasa, RD Congo

${ }^{5}$ Département des Sciences Biologiques, Université Laurentienne, Sudbury, Canada

Email: ^jpkabon2005@gmail.com, ${ }^{\star}$ getousfr2002@gmail.com

How to cite this paper: Khonde, P., Tshiabukole, K., Kankolongo, M., Hauser, S., Djamba, M., Vumilia, K. and Nkongolo, K. (2018) Evaluation of Yield and Competition Indices for Intercropped Eight Maize Varieties, Soybean and Cowpea in the Zone of Savanna of South-West RD Congo. Open Access Library Journal, 5: e3746.

https://doi.org/10.4236/oalib.1103746

Received: June 17, 2017

Accepted: January 2, 2018

Published: January 5, 2018

Copyright $\odot 2018$ by authors and Open Access Library Inc.

This work is licensed under the Creative Commons Attribution International License (CC BY 4.0).

http://creativecommons.org/licenses/by/4.0/

\begin{abstract}
In order to enhance the legumes potential advantages on the cereal yield in intercropping system by nitrogen direct transfer from legume to cereal, an intercropping experiment was conducted between eight maize varieties (07SADVE, 08SADVE 1, 09SADVE F2, Mudishi 1, Mudishi 3, VP0523, ZM538 and Sama$\mathrm{ru}$ ), cowpea (Vigna unguiculata var. H4) and soybean (Glycine max var. Vuangi) during November 2011-February 2012 season at INERA/Mvuazi in the south-western country of DR Congo. The experimental design was a Split plot with four replications, twenty six treatments were applied between maize varieties monocrops (40.000 plant.ha $\left.{ }^{-1}\right)$ and legumes in monoculture (360.000 plant $\cdot h \mathrm{a}^{-1}$ ) and both of sole planting were combined. Evaluation of these soles planting was performed on basis of several intercropping indices (MYE, LER, ATER, RCC, A and CR), the monetary advantage index (MAI), Actual Yield Loss index (AYL) and intercropping index (IA). After data analysis, competitivity indices indicated the higher yields advantages of maize varieties in intercropping, especially Mudishi 3-soybean $\left(\mathrm{MYE}=2836.300 \mathrm{~kg} \cdot \mathrm{ha}^{-1}\right)$. The equivalent land ratio (LER) varied with 08SADVE 1variety between 0.70 and 1.66 in cowpea and soybean intercrops respectively, the Relative crowding coefficient (RCC) showed yield advantage of all intercrops except with 09SADVE F2, Mudishi 1 and 07SADVE. Aggressivity (A) showed dominance of maize in all intercrops, against the Competitive ratio (CR) showed that the
\end{abstract}


competitivity was stronger on cowpea (from 16.42 to 98.63 ) than soybean (from 16.12 to 25.70). Actual yield loss (AYL) was negative in all intercrops with cowpea and soybean. Thus, the index of association (IA) informed that the negative values of the different intercrops were due to the maize price (1000 CDF. $\left.\mathrm{kg}^{-1}\right)$ and legumes price $\left(1500 \mathrm{CDF} \cdot \mathrm{kg}^{-1}\right)$. Finally, the monetary advantage index (MAI = 922.92) and PCA had determined that intercrop with Mudishi 3-soybean as an economic efficiency intercrop than others mixtures.

\section{Subject Areas}

Agricultural Science

\section{Keywords}

Intercropping, Maize, Legumes, LER, Monetary Advantage Index, DR Congo

\section{Introduction}

Intercropping has gained interest because of potential advantages it offers over yielding, i.e. improved utilization of growth resources by the crops and improved reliability from season to season. When a legume is grown in association with another crop (intercropping), commonly a cereal, nitrogen nutrition of the associated crop may be improved by direct nitrogen transfer from the legume to cereal [1]. Thus, several systems have been proposed to solve the problems of soil depletion [2] [3], among others the direct seeding mulch-based cropping systems (DMC) [4].

Studies carried out throughout the world have shown that the direct seeding mulch-based cropping system ensures a good productivity of the cultivated surfaces and gives many advantages in the soil management [5] [6] [7] [8] [9].

Intercropping of cereals with legumes has been popular in tropics [10] [11] and rain-fed areas of the world [12] [13] [14] [15] due to its advantages for soil conservation [16], weed control [17] [18], lodging resistance, yield increase [16] [19], and legume root parasite infections control [20].

Different seeding ratios or planting patterns for cereal-legume intercropping have been practiced by many researchers [15] [18] [21]. Competition among mixtures is thought to be the major aspect affecting yield as compared with solitary cropping of cereals [22].

Various measures of the efficiency of intercropping systems relative to sole cropping were employed [23]. A number of indices such as land equivalent ratio, area time equivalent ratio, relative crowding coefficient, competitive ratio, agressivity, actual yield loss, monetary advantage, and intercropping advantage have been proposed to describe competition within and economic advantages of intercropping systems [12] [13] [24] [25] [26]. Mathematical indices, formed by combining several primary measures, can help researchers summarize, interpret 
and display results from plant competition experiments [27]. However, the land equivalent ratio (LER) is the most-used convention for intercrop versus sole crop comparisons. Comparisons in competitive ability of the intercrop components were often made by calculating crowding coefficients and aggressivity values as in [28].

In this study we used a seedling model to determine whether the gaps considered for corn and DMC legumes can yield better yields relative to the yields of each monoculture crop and examine the ratios Competitiveness indices of maize and legumes in association cropping systems.

\section{Material and Method}

\subsection{Crop Management and Experimental Design}

The experiment was conducted at the INERA/Mvuazi Center, located in Kongo-Central province, $207 \mathrm{~km}$ south-west of Kinshasa $\left(5^{\circ} 27^{\prime} 08.77^{\prime \prime S}\right.$ et $14^{\circ} 53^{\prime} 20.34^{\prime \prime} \mathrm{E}$ at $427 \mathrm{~m}$ altitude) during 2011-2012 growing season. The climatic and edaphic characteristics of INERA/Mvuazi correspond to those of the tropical zone with warm and humid climate of type $\mathrm{AW}_{4}$ according to the classification of Köppen with 6 months of rainy season intercalated by a short drought (2 months), and followed of 4 months of dry season. Temperature variation and precipitation amount during the study period was presented in Figure 1. The soil of Mvuazi valley develops a humiferous horizon $15-25 \mathrm{~cm}$ thick, black (fresh) or brownish (dry) with a well-pronounced subangular or grumulous structure. This horizon is often overhauled by crops.

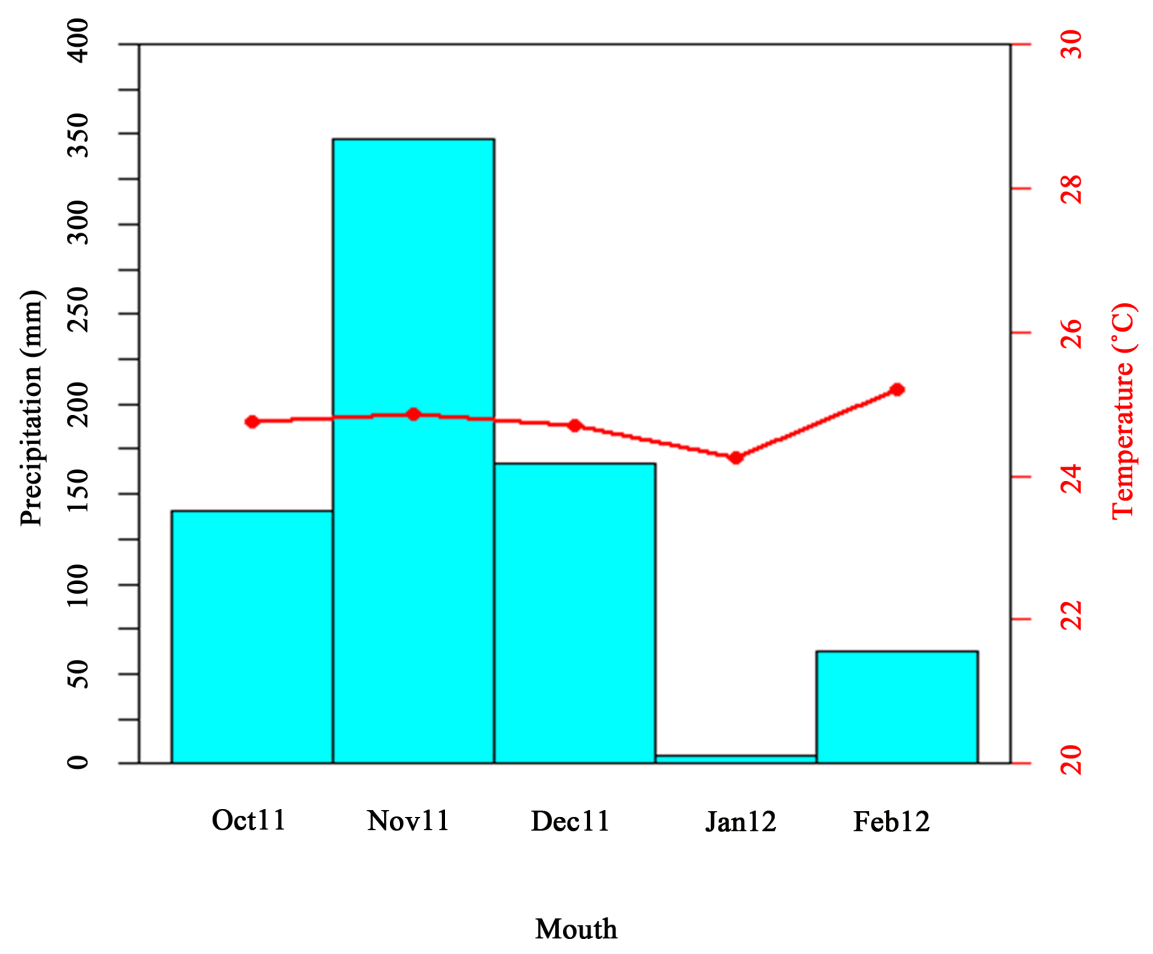

Figure 1. Temperature variation and precipitation amount during the study period. 
The experiment was in factorial design with 4 replications and treatments consisted to intercropping and sole cropping. Eight maize varieties, which five came from Zimbabwe (07 SADVE, 08 SADVE1, 09 SADVE-F2, ZM523, VP0538) and three local check of DR Congo (Mudishi1, Mudishi3 and Samaru) were sown at a spacing of $1 \mathrm{~m} \times 0.25 \mathrm{~m}$ in sole crop and intercrop with a density of 80.000 plants.ha ${ }^{-1}$, according to Paliwal et al. [29], in plots of $6 \mathrm{~m} \times 4 \mathrm{~m}$. Soybean (variety Vuangi) and cowpea (variety Diamand) were simultaneously planted with maize, at a spacing of $0.33 \mathrm{~m} \times 0.055 \mathrm{~m}$ in pure culture and sole crop and intercrop with a density of 360.00 plants.ha $^{-1}$. The pure culture for each variety was used as a control treatment.

\subsection{Competitions Indices and Monetary Advantages}

The competition effects between 3 species used in this experiment were calculated by using the indices of competition. Seeds of each species were weighed and adjusted on the constant levels of moisture, and maize was the principal crop and the legumes like components of intercrops. The maize yield of each plot was converted, for intercropping system, in maize equivalent yield (MEY) which was computed by converting yield of intercrop into the yield of maize on the basis of prevailing market prices of individual crops as [30]:

$$
\mathrm{MEY}=\mathrm{Y}_{\text {maize }}+\mathrm{Y}_{\text {legume }} \times \frac{P_{1}}{P_{2}}
$$

where, $\mathrm{Y}_{\text {maize }}$ and $\mathrm{Y}_{\text {legume }}$ are the yield of maize and legume in an intercropping system and $P_{1}$ and $P_{2}$ are the selling price of maize and legume, respectively. The advantage of intercropping and the effect of competition between the two species used in a mixture were calculated using different competition indices. The land equivalent ratio (LER) was used as the criterion for mixed stand advantage as both vetch and cereal were desired species [31]. In particular, LER indicates the efficiency of intercropping for using the resources of the environment compared with monocropping [32]. The value of unity is the critical value. When the LER is greater than 1 the intercropping favors the growth and yield of the species. In contrast, when LER is lower than 1 the intercropping negatively affects the growth and yield of the plants grown in mixtures [33] [34]. The LER was calculated as:

$$
\begin{gathered}
\mathrm{LER}=\left(\mathrm{LER}_{\text {mais }}+\mathrm{LER}_{\text {legumineuse }}\right) \\
\mathrm{LER}_{\text {maize }}=(\mathrm{Yml} / \mathrm{Ym}) \text {, et } \mathrm{LER}_{\text {legumineuse }}=(\mathrm{Ylm} / \mathrm{Yl})
\end{gathered}
$$

where $\mathrm{Yl}$ and $\mathrm{Ym}$ are the yields of legumes and maize, respectively, as sole crops and Ylm and $\mathrm{Yml}$ are the yields of legumes and maize as intercrops, respectively. The second index is the area time equivalent ratio (ATER) provides more realistic comparison of the yield advantage of intercropping over monocropping in terms of time taken by component crops in the intercropping systems. ATER was calculated by formula:

$$
\text { ATER }=\frac{1}{T} \sum_{1}^{n} \frac{d * \mathrm{Yi}}{\mathrm{Ym}} \quad \text { (Hauggaard-Nielsen et al., 2001) [10] }
$$


where $\mathrm{Yi}$ and $\mathrm{Ym}$ are yields of component crops in intercrop and monocrop system, respectively, and $n$ is the number of crops involved. $d$ is the growth period of the crop in days and $T$ is the time in days for which the field remained occupied i.e. the growth period of the longest duration crop. Numerical values of ATER approaches that of LER for a mixture consisting of crops of approximately identical growth periods i.e. when $t=d$ in comparison, productivity can also be expressed in terms of the resources use efficiency of the most limiting resource e.g., water, nutrients, energy or till. The interpretation of ATER involves that ATER $>1$ implies yield advantage; ATER $=1$ implies of no effect of intercropping; ATER $<1$ shows yield disadvantage [10].

The relative crowding coefficient (RCC or $\mathrm{K}$ ) is a measure of the relative dominance of one species over the other in a mixture [18] [35]. The $\mathrm{K}$ was calculated as:

$$
\begin{gathered}
\mathrm{K}=\left(\mathrm{K}_{\text {maize }} \times \mathrm{K}_{\text {legume }}\right) \\
\mathrm{K}_{\text {maize }}=\mathrm{Yml} \times \mathrm{Zlm} /((\mathrm{Ym}-\mathrm{Yml}) \times \mathrm{Zml}) \\
\mathrm{K}_{\text {legume }}=\mathrm{Ylm} \times \mathrm{Zml} /((\mathrm{Yl}-\mathrm{Ylm}) \times \mathrm{Zlm})
\end{gathered}
$$

where $\mathrm{Zml}$ and $\mathrm{Zlm}$ were the proportions of maize and legume in the mixture, respectively. When the value of $K$ is greater than 1, there is a yield advantage; when $\mathrm{K}$ is equal to 1 , there is no yield advantage; and when it is less than 1.00 , there is a disadvantage [15].

The next index was agressivity (A) which is often used to determine the competitive relationship between 2 crops used in the mixed cropping [28]. The agressivity was formulated as fallows [15]:

$$
\begin{aligned}
& \mathrm{A}_{\text {legume }}=(\mathrm{Ylm} / \mathrm{Yl} \times \mathrm{Zlm})-(\mathrm{Yml} / \mathrm{Ym} \times \mathrm{Zml}) \\
& \mathrm{A}_{\text {maize }}=(\mathrm{Yml} / \mathrm{Ym} \times \mathrm{Zml})-(\mathrm{Ylm} / \mathrm{Yl} \times \mathrm{Zlm})
\end{aligned}
$$

For cereal example: if $A_{\text {maize }}=0$, both crops are equally competitive, if $A_{\text {maize }}$ is positive, then the maize species is dominant, if $A_{\text {maize }}$ is negative, then the maize is the dominated species. Also, competitive ratio (CR) is another way to assess competition between different species. The CR gives a better measure of competitive ability of the crops and is also advantageous as an index over $\mathrm{K}$ and $\mathrm{A}$ [15] [36]. The CR represents simply the ratio of individual LERs of the two component crops and takes into account the proportion of the crops in which they are initially sown [37]. The CR is calculated according to the following formula:

$$
\begin{gathered}
\mathrm{CR}_{\text {maize }}=\left(\mathrm{LER}_{\text {maize }} / \mathrm{LER}_{\text {legume }}\right)\left(\mathrm{Z}_{\text {legume-maize }} / \mathrm{Z}_{\text {maize-legume }}\right) \\
\mathrm{CR}_{\text {legume }}=\left(\mathrm{LER}_{\text {legume }} / \mathrm{LER}_{\text {maize }}\right)\left(\mathrm{Z}_{\text {maize-legume }} / \mathrm{Z}_{\text {legume-maize }}\right)
\end{gathered}
$$

The next index that was used was the actual yield loss (AYL) index, which gave more accurate information about the competition than the other indices between and within the component crops and the behavior of each species in the intercropping system, as it is based on yield per plant [12]. The AYL is the pro- 
portionate yield loss or gain of intercrops in comparison to the respective sole crop, i.e. it takes into account the actual sown proportion of the component crops with its sole stand. In addition, partial $\mathrm{AYL}_{\text {legumes }}$ or $\mathrm{AYL}_{\text {maize }}$ represent the proportionate yield loss or gain of each species when grown as intercrops, relative to their yield in sole crop [15]. The AYL [38] was calculated as:

$$
\begin{aligned}
\mathrm{AYL} & =\mathrm{AYL}_{\text {maize }}+\mathrm{AYL}_{\text {legume }} \\
\mathrm{AYL}_{\text {maize }} & =((\mathrm{Yml} / \mathrm{Zml}) /(\mathrm{Ym} / \mathrm{Zm}))-1 \\
\mathrm{AYL}_{\text {legume }} & =((\mathrm{Ylm} / \mathrm{Zlm}) /(\mathrm{Yl} / \mathrm{Zl}))-1
\end{aligned}
$$

The AYL can have positive or negative values indicating an advantage or disadvantage remained in intercrops when the main aim is to compare yield on a per plant basis. Moreover, none of the above competition indices provides any information on the economic advantage of the intercropping system. For this reason, the monetary advantage index (MAI) was calculated as:

$$
\mathrm{MAI}=\frac{(\text { value of combined intercrops }) \times(\mathrm{LER}-1)}{\mathrm{LER}}
$$

The higher the MAI value the more profitable is the cropping system [13]. Also, intercropping advantage (IA) was calculated using the following formula [12]:

$$
\begin{aligned}
\mathrm{IA}_{\text {maize }} & =\mathrm{AYL}_{\text {maize }} \times \mathrm{P}_{\text {maize }} \\
\mathrm{IA}_{\text {legume }} & =A Y L_{\text {legume }} \times \mathrm{P}_{\text {legume }}
\end{aligned}
$$

where $\mathrm{P}_{\text {maize }}$ and $\mathrm{P}_{\text {legume }}$ are the commercial value of maize (the current price is 1000 FCD per $\mathrm{kg}$ ) and legumes (the current price of cowpea and soybean are 1500 FCD per kg) respectively. Data were analyzed using R 3.1.3 (2015) following standard Analysis of Variance procedures, and least significant difference (LSD) test at $5 \%$ probability level was used to compare all varieties of maize and each treatment means. Principal component analysis (PCA) was used to represent the correlations between yield and competitiveness-monetary indices was carried out to show the profitability of DMC systems.

\section{Results and Discussion}

\subsection{Yield and the Maize Equivalent Yield Index}

Regarding maize grain yield, a highly significant difference was observed ( $p<$ 0.001 ) between treatments (Table 1). Monocrop was higher (2350.2 kg.ha-1), compared to intercrops (1342.9 $\mathrm{kg} \cdot \mathrm{ha}^{-1}$ for cowpea and $2081.9 \mathrm{~kg} \cdot \mathrm{ha}^{-1}$ for soybean). Therefore, the best yield was recorded in monocrop of Samaru with $2849.44 \mathrm{~kg} \cdot \mathrm{ha}^{-1}$. This is similar to that obtained by KASETSART [39] in trials at the SUWAN farm in Thailand, where the yield of maize grown in monoculture was $31.9 \%$ higher than maize + soybean intercrop. A reasonable leaf area index (LAI) is essential to maintain high photosynthesis and yield [40]. Prasad and Brook [41] reported that the increase in maize density had a significant effect on LAI in maize-soya intercropping. 
Table 1. Grain yield and maize equivalent yield (MEY) in sole and intercropping treatments.

\begin{tabular}{|c|c|c|c|c|c|}
\hline \multirow{2}{*}{ Varieties } & \multirow{2}{*}{ Treatments } & \multicolumn{2}{|c|}{ Yield $\left(\mathrm{kg} \cdot \mathrm{ha}^{-1}\right)$} & \multirow{2}{*}{$\begin{array}{l}\text { Total Yield } \\
\left(\mathrm{kg} \cdot \mathrm{ha}^{-1}\right)\end{array}$} & \multirow{2}{*}{$\begin{array}{c}\text { Maize } \\
\text { equivalent Yield } \\
\left(\mathrm{kg} \cdot \mathrm{ha}^{-1}\right)\end{array}$} \\
\hline & & Maize & Legumes & & \\
\hline 07SADVE & monoculture & $2665.86 \mathrm{a}$ & - & $2665.86 \mathrm{a}$ & $2665.86 \mathrm{ab}$ \\
\hline 08SADVE1 & monoculture & $2129.52 \mathrm{a}$ & - & $2129.52 \mathrm{a}$ & $2129.52 \mathrm{ab}$ \\
\hline 09SADVEF2 & monoculture & $2128 \mathrm{a}$ & - & $2128 \mathrm{a}$ & $2128 \mathrm{ab}$ \\
\hline MUD1 & monoculture & $2402.4 \mathrm{a}$ & - & $2402.4 \mathrm{a}$ & $2402.4 \mathrm{ab}$ \\
\hline MUD3 & monoculture & $2283.62 \mathrm{a}$ & - & $2283.62 \mathrm{a}$ & $2283.62 \mathrm{ab}$ \\
\hline SAMARU & monoculture & $2849.44 \mathrm{a}$ & - & $2849.44 \mathrm{a}$ & $2849.44 \mathrm{ab}$ \\
\hline VP0538 & monoculture & $2277.22 \mathrm{a}$ & - & $2277.22 \mathrm{a}$ & $2277.22 \mathrm{ab}$ \\
\hline ZM523 & monoculture & $2065.53 \mathrm{a}$ & - & $2065.53 \mathrm{a}$ & $2065.53 \mathrm{ab}$ \\
\hline means & monoculture & $2350.20 \mathrm{a}$ & - & $2350.20 \mathrm{a}$ & $2350.20 \mathrm{ab}$ \\
\hline Niébé & monoculture & - & $178.2 \mathrm{~b}$ & $178.2 \mathrm{~b}$ & - \\
\hline Soya & monoculture & - & $1802.23 \mathrm{a}$ & $1802.23 \mathrm{a}$ & - \\
\hline 07SADVE & niébé & $1999.73 \mathrm{a}$ & $76 \mathrm{c}$ & $2075.73 \mathrm{abc}$ & 2050.39 \\
\hline 08SADVE1 & niébé & $1298.92 \mathrm{a}$ & $15.78 \mathrm{c}$ & $1314.7 \mathrm{bc}$ & 1309.44 \\
\hline 09SADVEF2 & niébé & $965.13 \mathrm{a}$ & $39.67 \mathrm{c}$ & $1004.8 \mathrm{bc}$ & 991.57 \\
\hline MUD1 & niébé & $753.6 \mathrm{ab}$ & $38.29 \mathrm{c}$ & $791.89 \mathrm{c}$ & 779.13 \\
\hline MUD3 & niébé & $1351.04 \mathrm{a}$ & $19.78 \mathrm{c}$ & $1370.82 \mathrm{bc}$ & 1364.23 \\
\hline SAMARU & niébé & $2028.88 \mathrm{a}$ & $96.14 \mathrm{c}$ & $2125.02 \mathrm{ab}$ & 2057.14 \\
\hline VP0538 & niébé & $1133.73 \mathrm{a}$ & $33.28 \mathrm{c}$ & $1167.01 \mathrm{bc}$ & 1155.92 \\
\hline ZM523 & niébé & $1212.45 \mathrm{a}$ & $68.2 \mathrm{c}$ & $1280.65 b c$ & 1227.92 \\
\hline means & niébé & $1342.94 \mathrm{c}$ & $48.39 c$ & $1391.33 \mathrm{bc}$ & $1381.65 \mathrm{~b}$ \\
\hline 07SADVE & soya & 2206.49 a & $546.92 \mathrm{~b}$ & $2753.41 \mathrm{a}$ & 2571.10 \\
\hline 08SADVE1 & soya & $2040.76 \mathrm{a}$ & $932.37 \mathrm{a}$ & $2973.13 \mathrm{a}$ & 2662.34 \\
\hline 09SADVEF2 & soya & $1843.63 \mathrm{a}$ & 885.49 a & $2729.12 \mathrm{a}$ & 2433.95 \\
\hline MUD1 & soya & $2113.15 \mathrm{a}$ & 859.44 a & $2972.59 \mathrm{a}$ & 2686.11 \\
\hline MUD3 & soya & $2291.12 \mathrm{a}$ & 817.77 a & $3108.89 \mathrm{a}$ & 2836.30 \\
\hline SAMARU & soya & 2113.9 a & $718.81 \mathrm{ab}$ & $2832.71 \mathrm{a}$ & 2593.11 \\
\hline VP0538 & soya & $1984.68 \mathrm{a}$ & 838.61 a & $2823.29 \mathrm{a}$ & 2543.75 \\
\hline ZM523 & soya & $2062.06 \mathrm{a}$ & $875.07 \mathrm{a}$ & $2937.13 \mathrm{a}$ & 2645.44 \\
\hline means & soya & $2081.97 b$ & 809.31 a & $2891.28 \mathrm{a}$ & $3295.94 \mathrm{a}$ \\
\hline$\alpha \mathbf{v}$ & ieties & ns & $* *$ & ns & ns \\
\hline$\alpha \operatorname{tre}$ & ments & $* *$ & $* * *$ & $* * *$ & $* * *$ \\
\hline a varietie & treatments & ns & ** & ns & ns \\
\hline
\end{tabular}

Means followed by the same letter in the columns do not differ by Tukey test $(p \leq 0.05)$; Statistical significance level: 0 “***»" 0.001 “**” 0.01 “*” 0.05 “ $\dagger$ ” 0.1 "ns" 1 . 
Variances analyses of legumes yield showed a highly significant difference ( $p$ $<0.001)$ between the treatments and significant difference $(p<0.05)$ between the interactions and varieties (Table 1). The soybean monocrop yield was greater $\left(1802.23 \mathrm{~kg} \cdot \mathrm{ha}^{-1}\right)$ than yield in maize intercrop $\left(809.31 \mathrm{~kg} \cdot \mathrm{ha}^{-1}\right)$. And then, the sole yield of cowpea was higher $\left(178.2 \mathrm{~kg} \cdot \mathrm{ha}^{-1}\right)$ than yield in maize intercrop (48.39 $\left.\mathrm{kg} \cdot \mathrm{ha}^{-1}\right)$. Hardter et al. [42] has already reported these, although maize and cowpea intercrop was lower than in rotation, sole crop continuously have lower productivities. While the pure leguminous plant cultures maintained their superiority on the mixed farming system only for soybean, the same proportion (50\% of soybean and $50 \%$ of cowpea) used in monoculture put in association, increased the outputs in grains of each variety of maize, but decreased those of soybean and increased that of cowpea.

The highest total mixed crop yield was obtained when Mudishi 3 was mixed with soybean (3108.89 $\mathrm{kg} \cdot \mathrm{ha}^{-1}$ ) (Table 1). MEY was to calculate and was higher in the system of soybean intercrop (Table 1) compared with monocultures.

Maize intercrops with soybean and cowpea had obtained higher maize equivalents yields than the total intercrops yields (Table 1). This can be allotted to the complementary effect of legumes in intercropping system by the nutritive transfer. Similar results were obtained by Ofori and Stern [33].

\subsection{Land Equivalent Ratio, Area Time Equivalent Ratio and Relative Crowding Coefficient}

Various competitive relationship of intercropping were computed and presented in Table 2. Results showed that maize partial LER were higher than 0.50 for all intercrops which indicates that there was an advantage for maize, except for Mudishi 1-cowpea (0.31) and VP0538-cowpea (0.46). The variance analysis showed that there was significant difference between Treatments $(p<0.05)$ for $\mathrm{LER}_{\text {maize }}$. On the other hand, all partial LER of cowpea was lower than 0.5 except intercrops with 07SADVE, Samaru and VP0538 which indicates that there was a disadvantage for cowpea. The partial LER of soybean were higher than 0.5 for all intercrops which indicates that there was an advantage for soybean [19], except intercrops with 07SADVE and Samaru.

LER showed the positive influences on growth and yield of maize and legumes intercrops (LER > 1) in maize-soybean intercrops with the greater for 08SADVE 1 -soybean (1.66). This indicates that $66 \%$ ( $0.66 \mathrm{ha})$ more area would be required by a sole cropping system to equal the yield of intercropping system [25]. In these cases, total LER was significantly different $(P<0.01)$ and values were higher than one showing the advantage of intercropping over sole stands in regard to the use of environmental sources for plant growth [32]. Similar results were reported for mix-proportions of pea-barley [19], bean-wheat [10], and maize-faba bean [43]. Partial LER values also showed that, compared to soybean, cowpea appears to have more beneficial land use efficiency in all mixtures.

LER doesn't consider the duration of the crops in the field and it is based on the harvested products, and not on desired yield proportion of the component 
Table 2. Land equivalent ratio (LER), area time equivalency ratio (ATER), relative crow ding coefficient (RCC or K), aggressivity (A) and competitive ratio (CR) for mixtures of height maize varieties and legumes (soybean and cowpea).

\begin{tabular}{|c|c|c|c|c|c|c|c|c|c|c|c|c|}
\hline \multirow{2}{*}{ Varieties } & \multirow{2}{*}{ Treatment } & \multicolumn{3}{|c|}{ LER } & \multirow{2}{*}{ ATER } & \multicolumn{3}{|c|}{ RCC or K } & \multicolumn{2}{|c|}{ A } & \multicolumn{2}{|c|}{$\mathrm{CR}$} \\
\hline & & LER $_{\text {maize }}$ & $\mathrm{LER}_{\text {legumes }}$ & Total & & $\mathrm{K}_{\text {maize }}$ & $K_{\text {legumes }}$ & Total & $A_{\text {maize }}$ & $A_{\text {legumes }}$ & $\mathrm{CR}_{\text {maize }}$ & $\mathrm{CR}_{\text {legumes }}$ \\
\hline 07SADVE & cowpea & $0.76 \mathrm{ab}$ & 0.63 & 1.39 & 1.32 & 60.32 & 3.41 & 172.72 & 0.173 & -0.17 & 20.96 & 0.09 \\
\hline 08SADVE1 & cowpea & $0.57 \mathrm{ab}$ & 0.12 & 0.70 & 0.64 & 59.24 & 0.016 & 1.67 & 0.14 & -0.14 & 56.22 & 0.032 \\
\hline 09SADVEF2 & cowpea & $0.63 \mathrm{ab}$ & 0.26 & 0.89 & 0.83 & -2.86 & 0.11 & 0.80 & 0.15 & -0.15 & 98.63 & 0.071 \\
\hline Mudishil & cowpea & $0.31 \mathrm{~b}$ & 0.38 & 0.69 & 0.66 & 4.62 & 0.12 & 0.62 & 0.068 & -0.067 & 16.42 & 0.17 \\
\hline Mudishi3 & cowpea & $0.61 \mathrm{ab}$ & 0.16 & 0.77 & 0.72 & 140.34 & 0.025 & 8.39 & 0.15 & -0.15 & 57.96 & 0.033 \\
\hline Samaru & cowpea & $0.73 \mathrm{ab}$ & 0.66 & 1.39 & 1.32 & -361.93 & 0.010 & 79.45 & 0.16 & -0.16 & 30.27 & 0.093 \\
\hline VPO538 & cowpea & $0.46 \mathrm{ab}$ & 0.31 & 0.78 & 0.73 & 39.23 & 0.057 & 3.38 & 0.11 & -0.11 & 13.79 & 0.084 \\
\hline ZM523 & cowpea & $0.61 \mathrm{ab}$ & 0.56 & 1.16 & 1.11 & -2.66 & -0.048 & 3.93 & 0.14 & -0.14 & 35.34 & 0.087 \\
\hline 07SADVE & soybean & $0.84 \mathrm{ab}$ & 0.38 & 1.22 & 1.15 & -65.92 & 0.104 & 0.71 & 0.20 & -0.20 & 25.70 & 0.053 \\
\hline 08SADVE1 & soybean & $1.00 \mathrm{a}$ & 0.67 & 1.66 & 1.57 & -71.98 & 0.098 & 76.31 & 0.23 & -0.23 & 17.10 & 0.07 \\
\hline 09SADVEF2 & soybean & $0.98 \mathrm{ab}$ & 0.58 & 1.56 & 1.47 & 32.26 & 0.26 & 11.03 & 0.23 & -0.23 & 19.72 & 0.088 \\
\hline Mudishil & soybean & $0.89 \mathrm{ab}$ & 0.59 & 1.48 & 1.40 & 147.01 & 0.45 & -10.04 & 0.21 & -0.21 & 16.73 & 0.070 \\
\hline Mudishi3 & soybean & $1.00 \mathrm{a}$ & 0.54 & 1.55 & 1.46 & 93.77 & 0.22 & 30.55 & 0.24 & -0.24 & 19.78 & 0.06 \\
\hline Samaru & soybean & $0.73 \mathrm{ab}$ & 0.46 & 1.19 & 1.13 & 56.01 & 0.14 & 4.47 & 0.17 & -0.17 & 18.05 & 0.074 \\
\hline VPO538 & soybean & $0.90 \mathrm{ab}$ & 0.56 & 1.45 & 1.37 & 271.71 & 0.26 & 24.84 & 0.21 & -0.21 & 16.12 & 0.067 \\
\hline ZM523 & soybean & $0.96 \mathrm{ab}$ & 0.57 & 1.53 & 1.44 & 2.22 & 0.24 & 8.14 & 0.22 & -0.22 & 18.04 & 0.086 \\
\hline \multicolumn{2}{|c|}{$\alpha$ varieties } & ns & $\mathrm{ns}$ & ns & ns & ns & $\mathrm{ns}$ & ns & ns & ns & $\mathrm{ns}$ & ns \\
\hline \multicolumn{2}{|c|}{$\alpha$ treatments } & $* * *$ & ns & $* * *$ & $* *$ & $\mathrm{~ns}$ & ns & ns & $* * *$ & $* * *$ & ns & ns \\
\hline \multicolumn{2}{|c|}{$\alpha$ varieties $\mathrm{x}$ treatments } & ns & ns & ns & $\mathrm{ns}$ & ns & ns & ns & ns & ns & ns & ns \\
\hline
\end{tabular}

Means followed by the same letter in the columns do not differ by Tukey test $(p \leq 0.05)$; Statistical significance level: 0 “***» 0.001 “**»" 0.01 “*” 0.05 “ $\nmid$ ” 0.1 "ns" 1.

crops. Moreover, the choice of sole cropped yield for standardizing mixture yield in the estimation of LER is not clear [28], therefore, area time equivalent ratio (ATER) provides more realistic comparison of the yield advantage of intercropping over sole cropping in terms of variation in time taken by the component crops of different intercropping systems [44].

The data presented in Table 2 showed that in all maize-legumes intercropping arrangements, the ATER values were lesser than LER values indicating the over estimation of resource utilization perhaps due to the wide variations in the maturity periods of the crops of which maize stayed longer on the land and had enough time to compensate for the legumes competition. ATER is free from problems of over estimation of resource utilization contrary to LER. ATER values showed an advantage of 57\% in 08SADVE 1-soybean (Table 2). This could be due to the reason of a significant effect on LAI in maize-soybean intercropping [41].

Although a statistical comparison among the partial $\mathrm{K}$ values of legumes and 
maize was not performed, it seems that the maize partial $\mathrm{K}$ was higher than legumes partial $\mathrm{K}$ in the case of the maize-cowpea mixtures and in maize-soybean mixture, indicating that maize is more competitive than its associated crop, except the cowpea intercropped with 09SADVE F2, Samaru and ZM523, and the soybean intercropped with 07SADVE and 08SADVE1 (Table 1). Similar results reported by Banik et al. [12] in chickpea-wheat intercropping and Dhima et al. [15] in cereal-vetch intercropping. The total $\mathrm{K}$ was above one in the case of all intercrops with cowpea and soybean, which indicates a definite yield advantage due to intercropping [12]. However, in the maize-cowpea mixture (09SADVE F2 and Mudishi 1) and in maize-soybean mixtures (07SADVE and Mudishi 1), the total $\mathrm{K}$ was below one, which indicates that there was a yield disadvantage [13] [36]. $\mathrm{K}$ values followed a similar trend with the LER values.

\subsection{Aggressivity, Competitive Ratio and Actual Yield Loss}

In all mixture, positive $A_{\text {maize }}$ values showed that maize was the dominant species (Table 2). Intercropped maize had higher competitive ratios (CRs) in all mixtures; however, cowpea had higher CR values than those of soybean with 09SADVE F2 (98.63), Mudishi 3(57.96) and 08SADVE1 (56.22) varieties. The results of competitive ratio index were also in corroboration with those of the aggressivity index. The values of A and CR for cowpea were indicated that cowpea was more competitive than soybean in maize mixtures. According to Yilmaz et al. [22], although increasing the cereal rate in mixtures elevated the crowding efficiency over legumes, doubling the rate per se may commence competition among maize plants, which probably resulted in weaker growth, thereby, lower $\mathrm{CR}$ and $\mathrm{A}_{\text {maize }}$ values. This was also confirmed with the negative $\mathrm{AYL}_{\text {maize }}$ values that were negative only when the maize ratio was the highest (Table 3 ). This was probably due to the fact that nitrogen fixing ability of the legumes did not compensate vigorous growth of cereals over a certain proportion.

In particular, $\mathrm{AYL}_{\text {maize }}$ had positive and the higher value only in Mudishi 3 -soybean intercropping, it was increase yield in this association with $0.41 \%$ $(0.0041)$ yield advantage compared to sole cropping. Which indicate a yield advantage for maize probably because of the positive effect of soybean on Mudishi 3 variety when grown in intercropping [12] [38]. According to Banik et al. [12], the AYL index can give more precise information than the other indices on the inter- and intra-specific competition of the component crops and the behavior of each species involved in the intercropping systems. Quantification of yield loss or gain due to intercropping with other species or the variation of the plant population could not be obtained through partial LERs, whereas partial AYL shows the yield loss or gain by its sign and as well as its value.

\subsection{Intercropping Advantages and Monetary Advantage Indexes}

Monetary advantage index followed the trend similar to LER (Table 3). The MAI values were positive under maize-soybean intercropping system (Table 3), which shows a definite yield advantage compared with the other intercropping 
Table 3. Actual yield loss (AYL), intercropping advantage (IA) and monetary advantage index (MAI) for mixtures of height maize varieties and legumes (soybean and cowpea).

\begin{tabular}{|c|c|c|c|c|c|c|c|c|}
\hline \multirow{2}{*}{ Varieties } & \multirow{2}{*}{ Treatments } & \multicolumn{3}{|c|}{ AYL } & \multicolumn{3}{|c|}{ IA } & \multirow{2}{*}{ MAI } \\
\hline & & Maize & Legumes & Total & Maize & Legumes & Total & \\
\hline 07SADVE & cowpea & $-0.24 \mathrm{~b}$ & -0.37 & $-0.61 \mathrm{abc}$ & $-240.25 \mathrm{~b}$ & -559.56 & $-799.81 \mathrm{abc}$ & $542.65 \mathrm{abcd}$ \\
\hline 08SADVE1 & cowpea & $-0.43 \mathrm{~b}$ & -0.88 & $-1.30 \mathrm{c}$ & $-428.30 \mathrm{~b}$ & -1314.39 & $-1742.69 c$ & $-396.14 \mathrm{~cd}$ \\
\hline 09SADVEF2 & cowpea & $-0.37 \mathrm{~b}$ & -0.74 & $-1.11 a b c$ & $-370.79 \mathrm{~b}$ & -1108.23 & $-1479.05 a b c$ & $-443.62 \mathrm{~d}$ \\
\hline Mudishil & cowpea & $-0.69 \mathrm{~b}$ & -0.62 & $-1.31 \mathrm{c}$ & $-687.57 \mathrm{~b}$ & -933.85 & $-1621.43 b c$ & $-315.78 \mathrm{bcd}$ \\
\hline Mudishi3 & cowpea & $-0.39 \mathrm{~b}$ & -0.84 & $-1.23 b c$ & $-390.83 \mathrm{~b}$ & -1255.86 & $-1646.69 \mathrm{bc}$ & $-396.60 \mathrm{~cd}$ \\
\hline Samaru & cowpea & $-0.27 \mathrm{~b}$ & -0.34 & $-0.61 \mathrm{abc}$ & $-270.12 b$ & -515.30 & $-785.42 \mathrm{abc}$ & $404.19 \mathrm{abcd}$ \\
\hline VPO538 & cowpea & $-0.54 \mathrm{~b}$ & -0.69 & $-1.22 b c$ & $-539.69 \mathrm{~b}$ & -1027.95 & $-1567.64 a b c$ & $-205.75 \mathrm{abcd}$ \\
\hline ZM523 & cowpea & $-0.39 \mathrm{~b}$ & -0.44 & $-0.84 a b c$ & $-391.47 \mathrm{~b}$ & -667.36 & $-1058.84 \mathrm{abc}$ & $-45.94 \mathrm{abcd}$ \\
\hline 07SADVE & soybean & $-0.16 \mathrm{a}$ & -0.62 & $-0.78 a b c$ & $-159.21 \mathrm{a}$ & -924.43 & $-1083.63 a b c$ & $353.93 \mathrm{abcd}$ \\
\hline 08SADVE1 & soybean & $0.00 \mathrm{a}$ & -0.33 & $-0.34 \mathrm{a}$ & $-2.76 \mathrm{a}$ & -500.99 & $-503.76 \mathrm{a}$ & $917.03 \mathrm{a}$ \\
\hline 09SADVEF2 & soybean & $-0.02 \mathrm{a}$ & -0.42 & $-0.44 \mathrm{ab}$ & $-24.63 \mathrm{a}$ & -628.57 & $-653.19 \mathrm{ab}$ & $752.41 \mathrm{ab}$ \\
\hline Mudishil & soybean & $-0.11 \mathrm{a}$ & -0.41 & $-0.52 a b c$ & $-107.29 \mathrm{a}$ & -620.89 & $-728.17 \mathrm{abc}$ & $742.39 \mathrm{ab}$ \\
\hline Mudishi3 & soybean & $0.0041 \mathrm{a}$ & -0.46 & $-0.45 a b$ & $4.11 \mathrm{a}$ & -686.30 & $-682.18 \mathrm{abc}$ & $922.92 \mathrm{a}$ \\
\hline Samaru & soybean & $-0.27 \mathrm{~b}$ & -0.54 & $-0.81 \mathrm{abc}$ & $-265.78 \mathrm{a}$ & -817.41 & $-1083.19 a b c$ & $353.38 \mathrm{abcd}$ \\
\hline VPO538 & soybean & $-0,10 \mathrm{a}$ & -0.44 & $-0.55 \mathrm{abc}$ & $-104.23 \mathrm{a}$ & -663.66 & $-767.88 \mathrm{abc}$ & $694.48 \mathrm{abc}$ \\
\hline ZM523 & soybean & $-0,04 \mathrm{a}$ & -0.43 & $-0.47 \mathrm{ab}$ & $-39.89 a$ & -645.7 & $-685.59 a b c$ & $913.41 \mathrm{a}$ \\
\hline \multicolumn{2}{|c|}{ a varieties } & ns & ns & ns & ns & ns & ns & ns \\
\hline \multicolumn{2}{|c|}{$\alpha$ treatments } & $* * *$ & ns & $* *$ & $* * *$ & ns & ** & $* * *$ \\
\hline \multicolumn{2}{|c|}{$\alpha$ varieties $\mathrm{x}$ treatments } & $\mathrm{ns}$ & $\mathrm{ns}$ & $\mathrm{ns}$ & ns & $\mathrm{ns}$ & $\mathrm{ns}$ & $\mathrm{ns}$ \\
\hline
\end{tabular}

Means followed by the same letter in the columns do not differ by Tukey test $(p \leq 0.05)$; Statistical significance level: 0 “ “**»” 0.001 “**” 0.01 “*” 0.05 “ $\dagger$ ” 0.1 "ns" 1.

systems tested in this study. In particular, the highest positive MAI values were for the Mudishi 3-soybean (+922.92), 08SADVE1-soybean (+917.03) and ZM523soybean (+913.41). The lowest monetary benefit was recorded in SAMARU-soybean $(+353.38)$. The other intercropping with cowpea showed negative MAI values, except 07SADVE-cowpea (+542.65) and SAMARU-cowpea (+404.19). Similarly, the IA, which is also an indicator of the economic feasibility of intercropping systems, indicated that most advantageous mixture was only for maize in Mudishi 3-soybean (+4.11). The fact that MAI and IA values were positive indicates that these intercropping systems had the highest economic advantage, whereas all the other mixtures, which had negative values, showed an economic disadvantage. These findings were also in agreement with the results of LER and the other competition indices (Table 1 and Table 2). Similarly, Ghosh [13] found that when the LER and $\mathrm{K}$ where higher there is also significant economic benefit expressed with 
higher MAI values.

The differences found between mixtures in this study can be attributed to aggressivity of maize and to other factors such as morphology, physiology and the different requirements for nutrients. In particular, the growing maize intercropped with cowpea can affect nitrogen fixation because of reduced light interception of cowpea due to shading by maize. This can result in poor nodulation, growth and competitive ability of cowpea compared to soybean in these mixtures. Also, the advantages of the intercropping systems found in this study can be attributed to the better utilization of growth resources [33]. For example, Osunde et al. [45] found that without the addition of fertilizer the proportion of $\mathrm{N}$ derived from $\mathrm{N} 2$-fixation was about 40 percent in the intercropped soybean and 30 percent in the sole crop, and with application of $40 \mathrm{~kg} \cdot \mathrm{N} \cdot \mathrm{ha}^{-1} \mathrm{~N} 2$-fixed by the sole cropped soybean was significantly greater than that fixed by intercropped system. However, to find out the real causes of these differences among mixtures examined in this study further research is required to study those factors.

\section{Principal Component Analysis}

In Figure 2, eigenvalues of principal components and percentage of the accumulated variable variance carried by them are given. For further analysis according to Keiser's criterion, first two components were >1 (Dim1 and Dim2). Those two principal components, which are a linear combination of the input data, explain over $80.72 \%$ of total variability.

The results of Figure 3 showed that dim 1 opposes maize-soybean intercrops to maize-cowpea intercrops. Maize-soybean intercrops is characterized by the LER, Am, Aleg, CRm, CRleg, ATER, MEY, MAI, AYL and IA indices, against maize-cowpea intercrops characterized by the Aleg index. As for Dim2, it opposes intercrops in terms of competitiveness. This dimension is characterized by two groups of more competitive maize varieties (09SADVE F2, 08SADVE 1 and Mudishi 3) and less competitive (Mudishi 1).

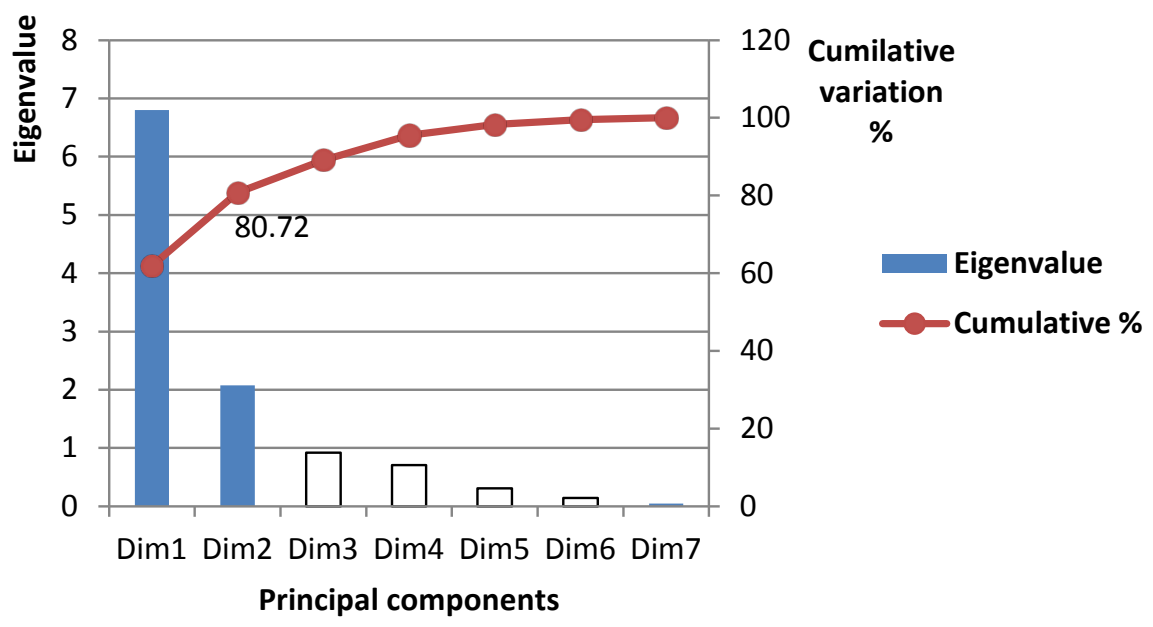

Figure 2. Scree plot. 


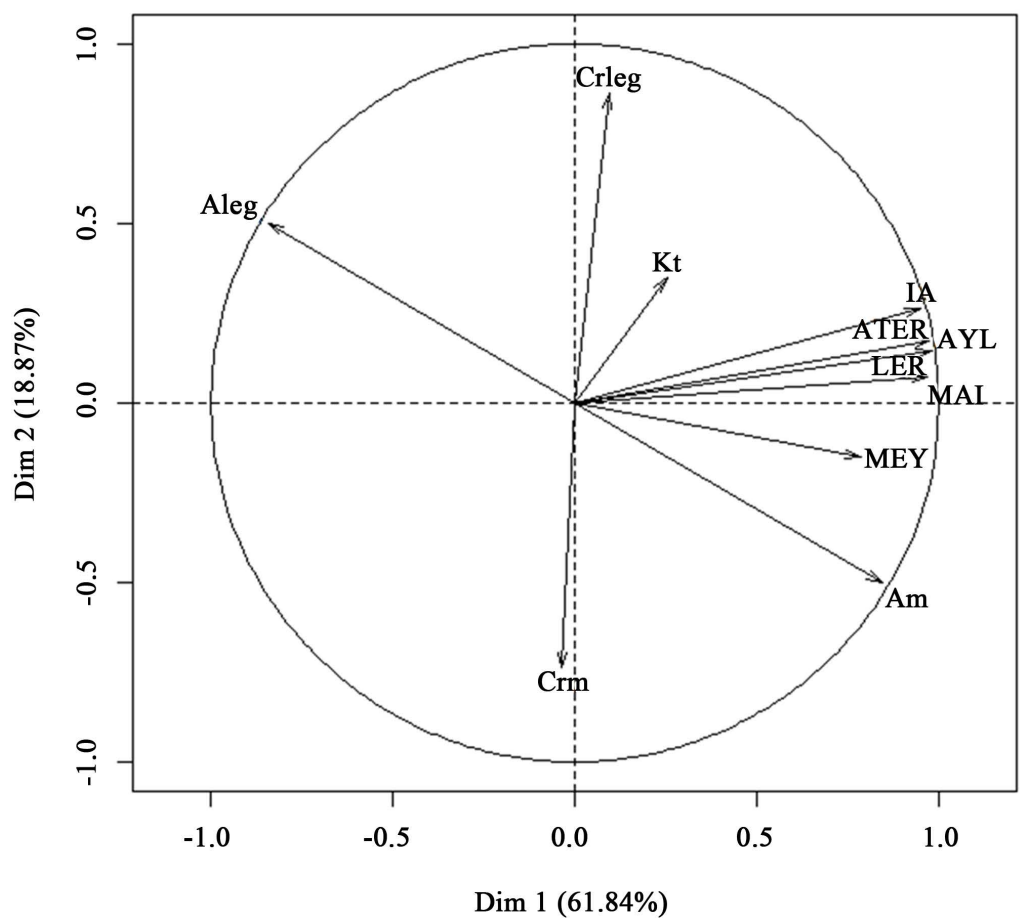

(a)

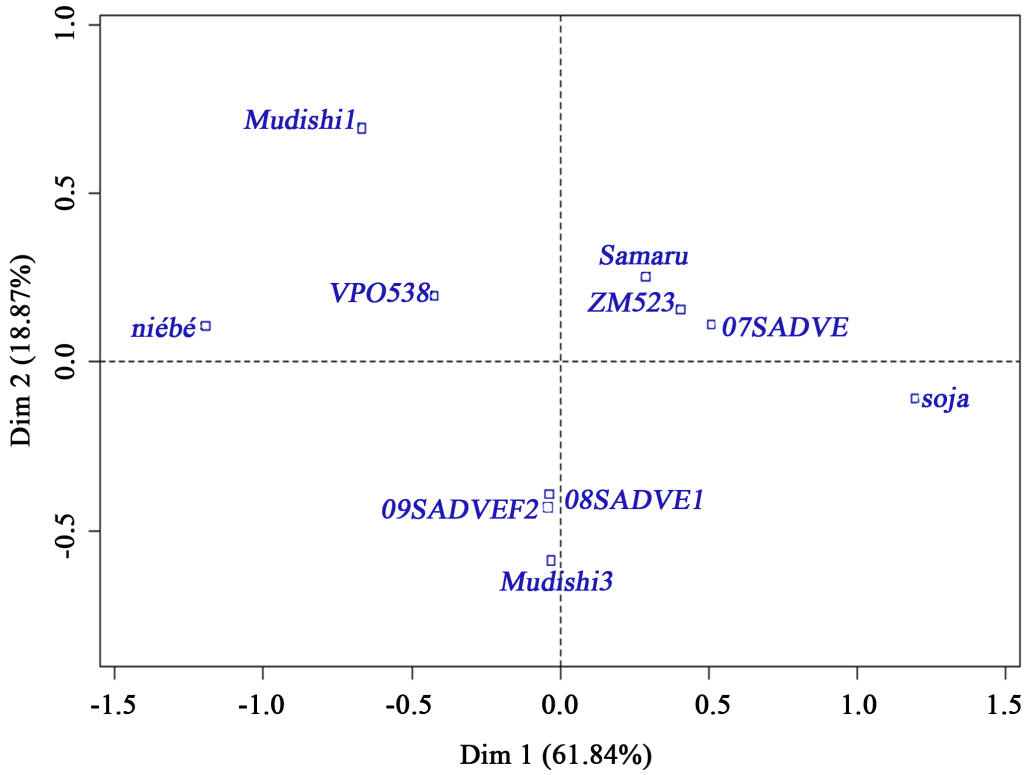

(b)

Figure 3. (a) Plane projection of the variables generated by the ACP of the studied parameters; (b) Varieties Distribution generated by Dim 1 and Dim 2 axes according to the ACP of parameters studied.

On the other hand, maize-soybean intercrops have had significant advantages, as confirmed by economic values (MAI) and land use efficiency (LER). The Mudishi 3 variety showed greater aggressiveness on cowpea and lower aggressiveness on soybeans. Mudishi 3-soya had the greatest monetary advantage, although the AI index was negative. 


\section{Conclusion}

The present study concludes that intercropping of maize with cowpea and soybean may affect seed yield, competition between the 2 species (maize and legumes), and economics of mixtures as compared to solitary cropping of the same species. Regardless of various varieties, maize-cowpea or maize-soybean intercropping had the yield advantages of intercropping and optimum exploitation of the environmental resources as opposed to other intercropping systems. Additionally, these 2 intercropping systems were observed to be the most profitable. Furthermore, cowpea intercropped with maize was more competitive than soybean. Generally, maize was the dominant species in all mixtures. Although legumes had lower yield in mixture but are more expensive in markets, solitary planting of them would not reach the profitable level gained with maize or other cereals cited in literature. On the other hand, mixtures with maize and soybean resulted in significant advantages of intercropping as confirmed by the economic and land use efficiency values. Mudishi 3 variety showed highest aggressivity for cowpea intercrop and lowness competitivity for soybean intercrop. Mudishi 3-soybean presented the greatest monetary advantage, although the intercrop advantage index was negative. Such a system can be easily practiced especially by peasants from the lower region in DR Congo, as well as in other countries that have similar climate. Therefore, with a higher socio-economic return for farming system, as well as soil conservation can be improved in such environments.

\section{Acknowledgements}

We would like to thank the staff of The National Institute of Study and Research Agronomy (INERA) and The International Institute of Tropical Agriculture (IITA) for this financial support.

\section{References}

[1] Giller, K.E. and Wilson, K.J. (1991) Nitrogen Fixation in Tropical Cropping Systems. CAB International, Wallingford, England, 167-237.

[2] Puckridge, D.W. and French, R.J. (1983) The Annual Legume Pasture in Cereal Ley-Farming Systems of Southern Australia: A Review. Agriculture, Ecosystems and Environment, 9, 229-267. https://doi.org/10.1016/0167-8809(83)90100-7

[3] Machet, J.M., Laurent, F., Chapot, J.Y., Doré, T. and Dutrout, A. (1997) Maîtrise de l'azote dans les intercultures et les jachères. [Mastery of Nitrogen in Intercultures and Fallows.] In: INRA, Ed., Maîtrise de l'azote dans les agrosystèrnes [Nitrogen Control in Agrosystems], Symposiums, N83, 271-288.

[4] FAO (2005) Regards sur l'agriculture de conservation en Afrique de l'ouest et du centre et ses perspectives. Contribution au $3^{\text {ème }}$ Congrès mondial d'agriculture de conservation à Nairobi, Rome, Italie, 114. [Perspectives on Conservation Agriculture in West Africa and Center and Its Perspectives. Contribution to the $3 \mathrm{rd}$ World Agriculture Congress of Conservation in Nairobi, Rome, Italy, 114.]

[5] Masson, P. and Bertoni, G. (1996) Essai d'enherbement d'un vignoble méridional à base de trèfle souterrain: Synthèse de six années d'expérimentation. In: XI Kollo- 
quium Begrünung im Weibau, Internationaler Arbeitsjkreis im Weinbau, Kaltern-Sud Tyrol, Italie, 28-31 août 1996.

[6] Thurston, D.H. (1997) Slash and Mulch Systems. Sustainable Methods for Tropical Agriculture. Westview Press, London, 196 p.

[7] Azontonde, A., Feller, C., Ganry, F. and Remy, J.C. (1998) Le mucuna et la restauration des propriétés d'un sol ferralitique au Sud du Bénin. [Mucuna and Restoration Properties of a Ferralitic Soil in Southern Benin.] Agriculture et Développement, 18, 55-62.

[8] Capillon, A. and Séguy, L. (2002) Ecosystèmes cultivés et stockage du carbone. cas des systèmes de culture en semis direct avec couverture végétale. [Cultivated Ecosystems and Carbon Storage. Case Direct Sowing Systems with Vegetal Cover.] C.R. Acad. Agri. Fr., 88, 63-70.

[9] CIALCA (2008) Rapport d'avancement 4-Bujumbura, Amélioration des moyens de vie basés sur l'agriculture en Afrique Centrale par le biais d'une productivité de systèmes durablement accrue en vue d'améliorer les revenus, la sécurité alimentaire et l'environnement. Réunion de lancement de CIALCA-II, Bujumbura, du 28 au 31 octobre 2008, 28. [Progress Report 4-Bujumbura, Improving the Means to Based on Agriculture in Central Africa through a Productivity of Sustainable Systems in Order to Improve Incomes, Food Security and the Environment. CIALCA-II Launch Meeting, Bujumbura, 28-31 October 2008, 28.]

[10] Hauggaard-Nielsen, H., Ambus, P. and Jensen, E.S. (2001) Evaluating Pea and Barley Cultivars for Complementary in Intercropping at Different Levels of Soil N Availability. Field Crops Research, 72, 185-196. https://doi.org/10.1016/S0378-4290(01)00176-9

[11] Tsubo, M., Walker, S. and Ogindo, H.O. (2005) A Simulation Model of Cereal-Legume Intercropping Systems for Semi-Arid Regions. II. Model Application. Field Crops Research, 93, 23-33.

[12] Banik, P., Sasmal, T., Ghosal, P.K. and Bagchi, D.K. (2000) Evaluation of Mustard (Brassica campestris var. Toria) and Legume in 1:1 and 2:1 Replacement Series System. Journal of Agronomy and Crop Science, 185, 9-14.

https://doi.org/10.1046/j.1439-037X.2000.00388.x

[13] Ghosh, P.K. (2004) Growth, Yield, Competition and Economics of Groundnut/Cereal Fodder Intercropping Systems in the Semi-Arid Tropics of India. Field Crops Research, 88, 227-237.

[14] Agegnehu, G., Ghizam, A. and Sinebo, W. (2006) Yield Performance and Land-Use Efficiency of Barley and Faba Bean Mixed Cropping in Ethiopian Highlands. European Journal of Agronomy, 25, 202-207.

[15] Dhima, K.V., Lithourgidis, A.A., Vasilakoglou, I.B. and Dordas, C.A. (2007) Competition Indices of Common Vetch and Cereal Intercrops in Two Seeding Ratio. Field Crops Research, 100, 249-256.

[16] Anil, L., Park, J., Phipps, R.H. and Miller, F.A. (1998) Temperate Intercropping of Cereals for Forage: A Review of the Potential for Growth and Utilization with Particular Reference to the UK. Grass and Forage Science, 53, 301-317. https://doi.org/10.1046/j.1365-2494.1998.00144.x

[17] Poggio, S.L. (2005) Structure of Weed Communities Occurring in Monoculture and Intercropping of Field Pea and Barley. Agriculture, Ecosystems \& Environment, 109, 48-58.

[18] Banik, P., Midya, A., Sarkar, B.K. and Ghose, S.S. (2006) Wheat and Chickpea Intercropping Systems in an Additive Series Experiment: Advantages and Weed 
Smothering. European Journal of Agronomy, 24, 325-332.

[19] Chen, C., Westcott, M., Neill, K., Wichman, D. and Knox, M. (2004) Row Configuration and Nitrogen Application for Barley-Pea Intercropping in Montana. Agronomy Journal, 96, 1730-1738. https://doi.org/10.2134/agronj2004.1730

[20] Fenandez-Aparicio, M., Josefina, C. and Sillero, D.R. (2007) Intercropping with Cereals Reduces Infection by Orobanche crenata in Legumes. Crop Protection, 26, 1166-1172.

[21] Tsubo, M., Walker, S. and Mukhala, E. (2001) Comparisons of Radiation Use Efficiency of Mono-Inter-Cropping Systems with Different Row Orientations. Field Crops Research, 71, 17-29.

[22] Yilmaz, S., Atak, M. and Erayman, M. (2008) Identification of Advantages of Maize-Legume Intercropping over Solitary Cropping through Competition Indices in the East Mediterranean Region. Turkish Journal of Agriculture and Forestry, 111-119.

[23] Hiebesch, C.K. and McCollum, R.E. (1987) Area $\times$ Time Equivalency Ratio: A Method for Evaluating the Productivity of Intercrops. Agronomy Journal, 79, 15-22. https://doi.org/10.2134/agronj1987.00021962007900010004x

[24] Hiebsch, C.K. (1980) Principles of Intercropping: Effect of N Fertilization and Crop Duration on Equivalency Ratios in Intercrops versus Monoculture Comparisons. $\mathrm{PhD}$ Thesis, North Carolina State University, Raleigh.

[25] Midya, A., Bhattacharjee, K., Ghose, S.S. and Banik, P. (2005) Deferred Seeding of Blackgram (Phaseolus mungo L.) in Rice (Oryza sativa L.) Field on Yield Advantages and Smothering of Weeds. Journal of Agronomy and Crop Science, 191, 195-201. https://doi.org/10.1111/j.1439-037X.2005.00157.x

[26] Lithourgidis, A.S., Valchostergios, D.N., Dordas, C.A. and Damalas, C.A. (2011) Dry Matter Yield, Nitrogen Content, and Competition in Pea-Cereal Intercropping Systems. European Journal of Agronomy, 34, 287-294.

[27] Weigelt, A. and Jolliffe, P. (2003) Indices of Plant Competition. Journal of Ecology, 91, 707-720. https://doi.org/10.1046/j.1365-2745.2003.00805.x

[28] Willey, R.W. (1979) Intercropping Its Importance and Research Needs. I. Competition and Yield Advantages. Field Crop Abstracts, 32, 1-10.

[29] Paliwal, L.R., Granados, G., Violic, A.D., Lafitte, H.R. and Marathee, J.P. (2002) Le maïs en zones tropicales: Amélioration et production. [Maize in Tropical Zones: Improvement and Production.] Food \& Agriculture Org., 382 p.

[30] Anuaneyulu, V.R., Singh, S.P. and Pla, M. (1982) Effect of Competition Free Period and Technique and Pattern of Pearl Millet Planting on Growth and Yield of Mungbean and Total Productivity in Solid Pearl Millet and Pearl Millet/Mungbean Intercropping System. Indian Journal of Agronomy, 27, 219-226.

[31] Willey, R.W. and Osiru, D.S. (1972) Studies on Mixtures of Maize and Beans (Phaseolus vulgaris) with Particular References to Plant Population. The Journal of Agricultural Science, 79, 519-529. https://doi.org/10.1017/S0021859600025909

[32] Mead, R. and Willey, R.W. (1980) The Concept of a "Land Equivalent Ratio" and Advantages on Yields from Intercropping. Experimental Agriculture, 16, 217-228. https://doi.org/10.1017/S0014479700010978

[33] Ofori, F. and Stern, W.R. (1987) Cereal Legume Intercropping System. Advances in Agronomy, 41, 41-90.

[34] Caballero, R., Goicoechea, E.L. and Hernaiz, P.J. (1995) Forage Yields and Quality of Common Vetch and Oat Sown at Varying Seeding Ratios and Seeding Rates of 
Common Vetch. Field Crops Research, 41, 135-140.

[35] De Wit, C.T. (1960) On Competition. Verslagen Landbouwkundige Onderzoekigen, 66, 1-82.

[36] Willey, R.W. and Rao, M.R. (1980) A Competitive Ratio for Quantifying Competition between Intercrops. Experimental Agriculture, 16, 117-125. https://doi.org/10.1017/S0014479700010802

[37] Esmaeili, A., Sadeghpour, A., Hosseini, S.M.B., Jahanzad, E., Chaichi, M.R. and Hashemi, M. (2011) Evaluation of Seed Yield and Competition Indices for Intercropping Barley (Hordeum vulgare) and Annual Medic (Medicago scutellata). International Journal of Plante Production, 5, 395-404.

[38] Banik, P. (1996) Evaluation of Wheat (Triticum aestivum) and Legume Intercropping under 1:1 and 2:1 Row-Replacement Series System. Journal of Agronomy and Crop Science, 176, 289-294. https://doi.org/10.1111/j.1439-037X.1996.tb00473.x

[39] Kasetsart University (1989) Annual Report. Department of Agronomy and National Corn and Sorghum Research Center, Bangkok.

[40] Xiaolei, S. and Zhifeng, W. (2002) The Optimal Leaf Area Index for Cucumber Photosynthesis and Production in Plastic Green House. ISHS Acta Horticulturae 633. http://www.actahort.org/books/633/633_19.htm

[41] Prasad, R.B. and Brook, R.M. (2005) Effect of Varying Maize Densities on Intercropped Maize and Soybean in Nepal. Experimental Agriculture, 41, 365-382. https://doi.org/10.1017/S0014479705002693

[42] Hardter, R., Horst, W.J., Schmidt, G. and Frey, E. (1991) Yields and Land Use Efficiency of Maize-Cowpea Crop Rotations in Comparison to Mixed and Monocropping on an Alfisol in Northern Ghana. Journal of Agronomy and Crop Science, 166, 326-337. https://doi.org/10.1111/j.1439-037X.1991.tb00922.x

[43] Li, L. (1999) Interspecific Facilitative and Competitive Interactions between Intercropped Species in Intercropping Systems. PhD Dissertation, China Agricultural University, Beijing.

[44] Aasim, M., Umer, E.M. and Karim, A. (2008) Yield and Competition Indices of Intercropping Cotton (Gossypium hirsutum L.) using Different Planting Patterns. Tarim Bilimleri Dergisi, 14, 326-333. https://doi.org/10.1501/Tarimbil_0000001048

[45] Osunde, A.O., Tsado, P.A., Bala, A. and Sanginga, N. (2004) Productivity of a Maize-Promiscuous Soybean Intercrops as Affected by Fertilizer in the Southern Guinea Savanna Zone of Nigeria. West African Journal of Applied Ecology, 5, 2004. 